Howard Nemorov, "Strange Metamorphosis of Poets," The Western Approaches (Chicago: University of Chicago Press, 1975), 6.

Paul Potts, "I have waited to ask you this," Commentary (November 1958), 410.

J. K. Stephen, "Sincere Flattery," The New Oxford Book of English Light Verse, 175. "Walt and Watts. (An Explanation)," Critic 7 (May 1982), 268.

Southwest Missouri State University

EDWARD A. MALONE

\title{
The Poets Continue to Respond: More Citations of Whitman as Poetic Subject
}

As Edward Malone's preceding list suggests, there is no end to the poems that deal in some essential way with Whitman. In my lengthy list, "The Poets Respond: A Bibliographic Chronology" (in Walt Whitman: The Measure of His Song), I attempted to trace the century-old tradition of poets who talked back to Whitman in their own poems or essays. Since that list was published, I have found many more poems and essays that should be included-some that I overlooked, some that have appeared recently. I have, however, given up on trying to make an exhaustive bibliography: new poems about Whitman are appearing all the time, and old ones from many languages keep turning up. The following list contains what seem to me the most significant poems to and about Whitman that were not included in my original bibliography. There are about two hundred additional poems here; it can serve to supplement and amplify Malone's list, and perhaps to inspire others to keep searching for poems that insist on Whitman's continuing presence. I would like to thank Jim Perlman, co-editor of Measure of His Song, for his help in identifying several of these poems.

B. Alkvit-Blum, "Dayne grozn" ["Your Grasses"], Lider (New York: CYCO, 1964), 77. [Yiddish. For citations of Yiddish poems to or about Whitman in addition to those listed here-including poems by Isaac Ronch, Chaim Schwartz, and Z. Weinper-see Leonard Prager, "Walt Whitman in Yiddish," WWQR 1 (December 1983), 22-35, and Aaron Kramer, "1881: Whitman's Impact on American Jewish Poetry," cited below.]

Barbara Anderson, "There and Here," Iowa Review 12 (Spring/Summer 1981), 1-2.

Antler, "Factory," "Whitmansexual," Last Words (New York: Available Press, 1986), 41-86, 163.

Willis Barnstone, "Walter Whitman," "Jiang Yuying, Famous Professor at Beijing University, Who Daringly Rendered into Chinese the First Complete Walt Whitman," 5 A.M. in Beijing (Riverdale-on-Hudson, NY: Sheep Meadow Press, 1987), $10,66-67$.

Robert Bly, "Whitman's Line as a Public Form," Selected Poems (New York: Harper and Row, 1986), 194-198. [Essay.] 
John Ciardi, "Quirks," Birds of Pompeii [Fayetteville: University of Arkansas Press, 1985), 10-11.

David Citino, "Walt Whitman in New Orleans, 1848," Last Rites \& Other Poems (Columbus: Ohio State University Press, 1980), 35; "At the American Anthropometric Society, Walt Whitman's Brain Is Dropped ..., " Mickle Street Review 3 (1981), 53.

Mattes Deutch, "Walt Whitman," The Golden Peacock, ed. Joseph Leftwich (New York: Thomas Yoseloff, 1951), 375-376. [Translated from Yiddish.]

Richard Eberhart, "Specifications," "Salute," "Great Principles Are Thrown Down by Time," The Long Reach (New York: New Directions, 1984), 75, 130, 140-141.

Calvin Forbes, "Reading Walt Whitman," The Poetry of Black America: Anthology of the 20th Century, ed. Arnold Adoff (New York: Harper and Row, 1973), 490.

Zona Gale, "Walt Whitman," Great Americans, as Seen by the Poets, ed. Burton Egbert Stevenson (Philadelphia: Lippincott, 1933), 350-351.

Allen Ginsberg, "I Love Old Whitman So," White Shroud: Poems, 1980-85 (New York: Harper \& Row, 1986), 58.

Michael Gold, "Ode to Walt Whitman," Social Poetry of the 1930s, ed. Jack Salzman and Leo Zanderer (New York: Burt Franklin, 1978), 88-91; "Towards Proletarian Art," Liberator (February 1921) [Essay under name of Irwin Granich]; reprinted in Mike Gold: A Literary Anthology, ed. Michael Folsom (New York: International, 1972), 67-70.

Kathryn H. Greenwood, "City Lover," "A Symposium on Whitman ..., " A Voice in the Crowd (Bloomfield, NJ: Vega Press, 1981); also in Mickle Street Review 1 (1979), 57; 3 (1981), 51-52.

William Heyen, "Bread," "Rails," "Shadow," "Island," "The Candle," "Walt's Light," Eight Poems for Saint Walt (Roslyn, NY: Stone House Press, 1985), 2-5, 8-11; "At West Hills, Long Island," The Ewe's Song (Concord, NH: William B. Ewart, 1980), reprinted in West Hills Review 3 (1981-1982), 112; "The Horse Chestnut," West Hills Review 4 (1983-1984), 129.

Langston Hughes, "I, Too," Selected Poems (New York: Vintage, 1974), 275.

Juan Ramón Jiménez, "Walt Whitman," Diario de Poeta y Mar (Buenos Aires: Editorial Losada, S.A., 1948), 172-173. [Prose poem. Spanish.]

Norbert Krapf, "Arriving on Paumanok," "The Roslyn Forge," "A Union Veteran from Indiana Recalls Visiting with Walt Whitman," "Walking with Walt Whitman and William Cullen Bryant," Arriving on Paumanok (Port Jefferson, NY: Street Press, 1979), 7, 17, 20-22, 26; "A Hoosier Song of Walt Whitman," Mickle Street Review 1 (1979), 62; "Flax," West Hills Review 4 (1981-1982), 131-132.

Aaron Kramer, "1881: Whitman's Impact on American Jewish Poetry" [Essay], The Burning Bush (New York: Cornwall, 1983), 218-227; "Legacy," Mickle Street Review 8 (1986), 72.

Aaron Kurtz, "Walt Whitman," "Ikh bin gegangen zen volt vitman," Lider (New York: Aaron Kurtz Book Committee, 1966), 214-220, 360-361. [Yiddish.] 
James D. Law, "To Walt Whitman," December 1889, unpublished poem, Bolton, England, Metropolitan Library, Whitman Collection.

Larry Levis, "Whitman:," Winter Stars (Pittsburgh: University of Pittsburgh Press, 1985), 63-64. [Originally in Walt Whitman: The Measure of His Song.]

H. Leyvik, "To America," American Yiddish Poetry, ed. Benjamin and Barbara Harshav (Berkeley: University of California Press, 1986), 762-769. [Yiddish, with translation.]

Robert Lowell, "Bishop Berkeley," Notebook (New York: Farrar, Straus and Giroux, 1970), 168; "Shadow," Day by Day (New York: Farrar, Straus and Giroux, 1977), 116-117.

Reuben Ludwig, "Symposium," Amerike in yidishn vort, ed. Nakhmen Mayzl (New York: YKUF, 1955). [Yiddish.]

Arthur Lundkvist, "Whitman," Naket Liv (Stockholm: Albert Bonniers Forlag, 1929), 64-65. [Swedish.]

Tom MacInnes, "To Walt Whitman," Book of Canadian Poetry, ed. A. J. M. Smith (Toronto: W. J. Gage, 1957), 224-225.

Helene Margaret, "Song of the Answerer (A Reply to Walt Whitman)," Anthology of Magazine Verse for 1938-1942, ed. Alan F. Pater (New York: Paebar Co., 1942), 300-301.

L. Miller, "Ikh her dayn kol, volt vitman," Amerike in yidishn vort, 435-436. [Yiddish.]

Gary Miranda, "Second-born Son (Lines for Walt Whitman Composed on Nantucket Island)," Listeners at the Breathing Place (Princeton: Princeton University Press, 1978), 41-43.

Mayhew Mott, "Mollie and I (August, 1885)," in Poems Out of Wisconsin, ed. Maude Totten (Oshkosh: Castle-Pierce, 1961), 64-65.

Sharon Olds, "Nurse Whitman," "The Language of the Brag," Satan Says (Pittsburgh: University of Pittsburgh Press, 1980), 13, 44-45; "Federal Street at Night," Mickle Street Review 1 (1979), 78.

George Oppen, "Of Being Numerous," Collected Poems (New York: New Directions, 1975), 145-179.

Simon Ortiz, "From Sand Crek," From Sand Creek (Oak Park, NY: Thunder's Mouth Press, 1981), 80-81.

Jophn Burdett Payne, "Emily and Walt, Walt and Emily," ManRoot 6-7 (1972), 64-66.

Anthony Piccione, "With Whitman at the Friendship Hotel," Seeing It Was So (Brockport, NY: BOA Editions, 1986), 57.

Leonard Randolph, "Ignoring Whitman," Wind Over Ashes (Carolina Wren Press, 1982), 47-48.

Lincoln Reis, "Walt Whitman," Off to Arcady, ed. Max J. Herzberg (New York: American Book Co., 1933), 432-433. 
William Pitt Root, "The Names of the Dead ...," Reasons for Going It on Foot (New York: Atheneum, 1981), 49; "Pome Ex Cathedra from The Adventures of Pome," Mickle Street Review 3 (1981), 58.

H. Rosenblatt, "America," Amerike in yidishn vort, 236. [Yiddish.]

Morris Rosenfeld, "Walt Whitman," Modern Yiddish Poetry: Anthology, ed. Samuel J. Imber (New York: East and West, 1927), 268-269; The Golden Peacock, 104. [Translated from Yiddish.]

James Schevill, "Whitman Stock-Taking, Cataloguing," "Science Fiction: Dizzying Changes in America," The American Fantasies (Athens, OH: Swallow Press, 1983), 15-16, 60; "At Whitman's House in Camden," West Hills Review 5 (1985), 118.

Dave Smith, "On a Field Trip at Fredericksburg," The Roundhouse Voices (New York: Harper and Row, 1985), 20-21.

Jordan Smith, "Cedar Shoals," Shenandoah 32 (1982), 101-102.

James Kenneth Stephen, "Of W.W. (Americanus)," What Cheer, ed. David McCord (New York: Coward-McCann, 1945), 275.

Annie Thomas, "To Walt Whitman," Werner's Readings and Recitations (New York: Edgar S. Werner, 1905), 194-195.

Charles Tomlinson, "A Garland for Thomas Eakins," Selected Poems, 1951-1974 (Oxford: Oxford University Press, 1978), 76-79; "Crossing Brooklyn Ferry," "Hero Sandwiches," Notes from New York (Oxford: Oxford University Press, 1984), 16, 23.

Diane Wakoski, "Letter with the Ring of Truth," The Rings of Saturn (Santa Rosa: Black Sparrow Press, 1986), 97-100.

E. B. White, "A Classic Waits for Me," What Cheer, 200-202.

Marguerite O. B. Wilkinson, "Whitman and Emerson," Lyric Year, ed. Ferdinand Earle (New York: Mitchell Kennerley, 1912), 283-284.

Kip Zegers, "The Promise Is," Ironwood 11 (Spring 1983), reprinted in Mickle Street Review 8 (1986), 70-71.

Paul Zimmer, "Leaves of Zimmer," Family Reunion (Pittsburgh: University of Pittsburgh Press, 1983), 41.

Many poems relating to Whitman appear in the annual issues of the Mickle Street Review and West Hills Review; some are reprints and others are inspired by Whitman rather than about or to him. Following is a list of poems about or to Whitman that either first appeared in $M S R$ or are reprinted but not easily available elsewhere. I have not included poems that are in the above list or in my Measure of His Song bibliography:

Number 1 (1979): Kate Britt, "To Walt Whitman," 32; Norman Friedman, "The Magic Badge, Or, Song of Myself 100 Years After," 39-44; Paul Fericano, "Loading the Revolver with Real Bullets," 51-52; J. H. Bowden, "The Walt Whitman Shopping Center," 58; Michael Rumaker, "Yet Another Poem Addressed to Walt Whitman," 59-61; Robin Hiteshew, "Camden: A Visit to Whitman's," 63; Elmira Bussey, "Walt Whitman on the Subway," "Brothers of the Rolling Earth," "The Open 
Road," 64-65; Robert Vas Dias, "Brooklyn," 67; Juniper Violet, "Love Song to the Earth," 69-72; Gail Kadison Golden, "the monument," 73; Ernest Stefanik, "Not till the Sun Excludes," 74; Henry Petroski, "Try Sheet," 75; Lyle Tatum, "New Jersey," 76-77; Carolyn Carson, "Walt," 79; Jeff Branin, "God, Do I Love Reading Whitman," "On Comparing Whitman's Leaves with Uncle Nick Grindstaff's Tombstone . . . ," 80; Sandra Hoben, "Before I'm Awake," 82; John Mann, "Lines for W.," 83; Barbara Adams, "Avenue of the Americas," 84-85; Candice Warne, "A Student Apologizes," 86; Jeanne Lohmann, "On Studying Whitman Indoors," 87; Lolette Escoe, "For Walt Whitman," 88; Jim Farrell, "Lunch with Allen," 89; Fred Johnson, "America," 91-92.

Number 2 (1980): Norman MacAfee, "O Walt Whitman," 16-17; Ken Fontenot, "Friends," 20-21; Judith Saul Stix, "To You, Walt, and to Others," 22; Jean E. Pearson, "All the Beautiful Singers," 40-41; Jon Bracker, "In Golden Gate Park," 50; Daniel Wolff, "Visitors," 51; Joy Walsh, "Paumanok," 54-55; Martin Itzkowitz, "Dear Walt," 80.

Number 3 (1981): John J. Soldo, "A Whitman Man," 23; Edith Segal, "An Unsent Letter," 35-37; Dan Gerber, "A Fine Excess," 38-39; Peter Hoheisel, "Breaking the Hypnosis," 40; Lawrence Hayes, "The Caller of Birds," 41-42; Marc Widershien, "From Breaking the Net," 43; Robert Sargent, "Ezra's Pact," 46; Joanne Seltzer, "Anthology," 48-49; Ida Fasel, "Researcher," 50; Sanford Pinsker, "American Poetry," "The Patient, Noiseless Spider . . . ," 54; Lasse Soderberg, "With My Heart's Chalk," 55; David R. Slavitt, "Two Stanzas from Dozens," 59; David Walker, "Beginning the Garden," 60; Lois V. Walker, "The American Stream," 62; Nancy Westerfield, "Bringing It to You with Full Hands," 67; Ennis Rees, "In Morgan's Hall," 68; George Bishop, "To Walt Whitman," 69; Stephen Knauth, "The Night Whitman Died," 79; Franz Douskey, "Escape from the Lost City," 83; Paul Rice, "Meeting the Ghost of Walt Whitman ... ," 84; Joseph Lisowski, "Virginia State Penitentiary Blues," 85; Gary C. Busha, "A Celebration for Whitman," 88; Gerald Parks, "Poetry and the Noise of Traffic," 90-91; J. Lawrence Lembo, "Walt Whitman Breathes Here," 92-94; Martin Tucker, "What Whitman Would Have Seen Sunday," 95.

Number 4 (1982): Roger Mitchell, "To Walt Whitman on America's Birthday, 1978," 54-55; B. Z. Niditch, "Walt Passed By," 55; Elizabeth Searle Lamb, "At Cranberry and Fulton Streets," 56; Howard Nelson, "Reading "Crossing Brooklyn Ferry' ...," 57; Lamont B. Steptoe, "On Reading Walt Whitman," 80-81.

Number 5 (1983): Michael Chandler, "The Spirit of Whitman," 5; Jim Mele, "Thoreau Believed," 16; Barbara Adams, "Under Wear," 24; Cynthia R. Golderman, "Goodbye My Fancy!," 46.

Number 6 (1984): Bruce Agte, "The Glass Shop," 9-12; S. L. Berry, "In a Restaurant with Walt Whitman," 16-17; Jon Bracker, "To the Staten Island Ferry," 31; Lesley Choyce, "Eva on View," 54; Tony Cosier, "Distances," 55-56; Kavirag George Dowden, "I Lay in Whitman's Deathbed," 56-58; Charles Ghigna, "Whitman: The Fisherman," 62; Cynthia Golderman, "Working with Walt Whitman," 63-64; David Hilton, "The Eye," 69; Thomas Lisk, "Logo Traubel," 74-77; Jean Pearson, "A Wisconsin Shaman," 94-95; Ulrich Troubetzkoy, "Waiting for Walt Whitman," 108-110; David Zeiger, "Walt Whitman Walks Manhattan, 1842," 114. 
Number 7 (1985): Randall R. Friesinger, "Walt Whitman at Timber Creek," 9-10; Jeffrey Collins, "At the Astronomy Lecture," 106; Jim Peterson, "A Wrestler of Trees," 108-109.

Number 8(1986): Gilbert Allen, "Sonnet \$9.95," 4; Bruce Agte, "Rust," 17; Nathaniel Philbrick, "Walt Whitman at Edgar Allan Poe's Funeral," 60; Macushla Nugent, "Whitman Comes to Baltimore," 60; Elliot Richman, "To My Head Expander, Not My Shrink," 73-74.

Poems about or to Whitman originally appearing in the West Hills Review, volumes 1 and 2, were included in the bibliography in Measure of His Song; relevant poems in subsequent volumes include:

Volume 3 (1981-1982): Daisaku Ikeda, "When I hear the name Whitman," 33; Robert Sargent, "Dressing with Whitman," 97; Charles Semones, "To Walt Whitman on His Sixty-Ninth Birthday," "Walt Whitman in Harrodsburg, 1982," 99-100; William Slaughter, "Fulbrighting in Egypt," 104; James Snydal, "March in Camden, 1982," 109.

Volume 4 (1983-1984): Jack Hand, "In Whitman's Dooryard," 121-122; Jennie Hair, "Whitman Underfoot," 126; Marc Widershien, "Pictures from Mathew Brady," 137138.

Volume 5 (1983-1984): B. Z. Niditch, “A Day with Walt Whitman," 105.

Volume 6 (1986): Robert Spencer, "Whitman," 87.

The University of Iowa

Ed Folsom

\section{AdDitional Whitman Allusions in HARPER'S MONTHLY}

Daniel A. Wells covered a lot of ground in assembling his annotated bibliography of references to Whitman in Harper's from 1860 to 1896 (WWQR 4 [Summer 1986], 16-23). However, if he had consulted my Walt Whitman, 1838-1939: A Reference Guide (G. K. Hall, 1981), he would have discovered four more, which I present here for completion's sake:

67 (October 1883), 798.

Henry Mills Alden, writing anonymously here (as in the January 1882 item that Wells lists), reviews Sidney Lanier's posthumous The English Novel and the Principle of Its Development (1883), noting his "refutation of the crude theories of imaginative art advanced by Walt Whitman and Emile Zola."

77 (November 1888), 967.

W. D. Howells in "Editor's Study" anonymously reviews volumes of poetry by Charles Leonard Moore and W. E. Henley, which "have the same claim through the same divine art-the art of John Keats, the art of Walt Whitman-to the world's attentive regard." 